Original Article

\title{
Clinical features of the arterial hypertension in a medical emergency service in Abidjan
}

\author{
A. D. Diallo, M. B. Mouanodji, E. K. Niamkey and B. B. Yao \\ Departement of Internal Medecine of Treichvillc Teaching.
}

\begin{abstract}
The authors studied the clinical features of high hypertension (blood pressure over $240 \mathrm{mmhg}$ for the systolic and over $140 \mathrm{mmhg}$ for the diastolic pressure) in 300 black African patients observed in the unit of medical emergency at Abidjan.

In this unit arterial hypertensions represented $8.27 \%$ of the cases and was the main cause of mortality ( $12.9 \%$ VS $7.2 \%$ for the others causes).

The common complications were heart failure (29\%) stroke $(21 \%)$, encephalopathy $(19 \%)$ and renal failure $(16 \%)$. Diabetes was associated in $8.33 \%$ of cases. The high rate of mortality is observed when there was stroke (25.4\%) and renal failure (25\%).

There was significant increase in mortality linked to high blood pressure.
\end{abstract}

Key words: Arterial hypertension; renal failure; stroke

\section{Introduction}

It is well established that arterial hypertension (AHT) is sever and more frequent in black Africans than in whites.

In Africa, arterial hypertension affects about 10 to 15 $\%$ of population and 5 to $12 \%$ of hospitalised patients [3].

The aim of this work was to study the different clinical features of high blood pressure fover 240 mmhg for systolic (SBP) and $140 \mathrm{mmhg}$ for diastolic

Correspondence and offprim requests to: Dr. A. D. Diallo, Depanement of Internal Medecine of Treichville Teaching. 21 BP 844 Abidjan. blood pressure (DBP)\} among patients presented to the medical emergency unit and to assess the hypertensive complicalions.

\section{Materials and methods}

From March 1991 10 March 1992, 300 cases with arterial hypertension among a total of 7491 patients presented to the medical emergency service of Treichville Teaching Hospital. All patients were black Africán.

We measured blood pressurc whith sphygmomanometer while pationts at rest and in lying position. Hypertension was diagnosed if arterial pressure was above or equal to $160 \mathrm{mmh}$ for systolic and or 95 mmh for diastolic blood pressurc.

We studied age, scx, blood pressurc, visceral complications, associated factors and mortality at short term. Heart failurc, ccrebral stroke and hypertensive encephalopathy had been diagnosed on the basis of clinical aspects and complementary test. Renal function was estimated by the level of scrum creatinine in 149 cases.

\section{Results}

Epidemiological aspects

Three hundred patients were included, 116 Women $(38.7 \%)$ and 184 Men $(61.3 \%)$. Their ages ranged from 16 to 89 years. The average age was $51.08 \pm$ 14.70 years for men and $50 \pm 13.69$ for women. 
Most of these patients $(58 \%)$ were from lower socioeconomic calss with precarious financial means. The main functional symptoms were as follow: dizzinness $(38.33 \%)$, headaches $(35 \%)$ and eye troubles $(15.7 \%)$.

\section{Blood pressure figures on admission}

According to these figures, patients had been divided into four groups (A, B, C, D) as shown in table 1 .

Table 1. Distribution according to the tensional figures on admission

\begin{tabular}{|c|c|c|c|}
\hline Group & Blood pressure & $N$ & $0 \%$ \\
\hline A & $\begin{array}{r}140<\mathrm{SBP}<240 \\
80<\mathrm{DBP}<140\end{array}$ & 236 & 78.8 \\
\hline B & $\begin{array}{r}\mathrm{SBP}>240 \\
80<\mathrm{DBP}<140\end{array}$ & 18 & 6 \\
\hline $\mathrm{C}$ & $\begin{aligned} 140<\mathrm{SBP} & <240 \\
\mathrm{DBP} & <140\end{aligned}$ & 20 & 6.6 \\
\hline D & $\begin{array}{l}\mathrm{SBP}>240 \\
\mathrm{DBP}>140\end{array}$ & 26 & 8.6 \\
\hline
\end{tabular}

\footnotetext{
A.H.T = Arterial hypertension

$=$ A.H.T. from moderate 10 severe

$=$ High systolic A.H.T

$=$ High diastolic A.H.T.

$=$ High A.II.T.
}

\section{Visceral complications}

- Ncuro Sensorial complications:

A neurosensorial attack was observed in 120 cáses (40\%).

- Hypcrtensive encephalopathy was seen in 57 cases (19\%) among which there were:

25 cases of coma (26.32\%), 10 cases of convulsions $(17.54 \%)$ and 7 cases of loosing conscious ( $12.28 \%$ ).

- Cercbral strock occurred in 63 cases including: 25 cases $(39.68 \%)$ of transient cerebro-vascular accident (C.V.A) and progressives C. A. V. characterised by a neurological deficiet lasting more than 24 hours in 38 cases $(60.32 \%)$.

- Cardiovascular complications:

It was observed in 87 patients (89\%), left ventricular failure in 63 cases $(72.47 \%$ ) and a global cardiac failure in 24 cases $(27.5 \%)$.

Chest $X$ ray was done in 41 cases which revealed cardiomegaly in 24 patients. ECG was done in 39 patients, abnormalities were present in 24 of them as: left ventricular hypertroph! with left ventricular over load, ventricular extrabeat and left bundle block.

Echocardiography was done in 11 patients. It showed hypertensive cardiomyopathy in all patients.

- Renal complications:

It was observed in 48 cases $(16 \%)$ of our patients. It was functional acute renal failure in $21 \%$ and chronic renal failure in $79 \%$ with a high serum creatinine up to $20 \mathrm{mg} / \mathrm{l}$.

\section{Malignant arterial hypertension}

Twelve cases of malignant hypertension had been observed in this group (300 subjects), with a prevalence of $4 \%$. These patients presented with a DBP $>130 \mathrm{mmhg}$, heart and renal failure and occular fundal changes (stage III or IV). This group included 9 men $(75 \%)$ and 3 women $(25 \%)$.

The mean age of these patients was $47.83 \pm 9.12$ years. The average blood pressure was $244.16 \pm$ $27.12 \mathrm{mmhg}$ and $147.5 \pm 14.85 \mathrm{mmhg}$ for systolic and diastolic respectively. The mortality in this group was $25 \%$.

\section{Hypertension and diabetes}

The association of hypertension and diabetes had bean observed in 25 patients: 20 cases of diabetes type 11 and 5 cases of diabetes types I (insulindependant).

\section{Etiological aspects}

In this work $85 \%$ (255 cases) of the whole group their hypertension seemed to be essential.

We found some etiological causes which were as follow:

- Gravidic hypertension: 1 case

- Poiycystic Kidney disease: 4 cases

- Chronic glomeruionephritis: 12 cases

- Chronic hypertensive nephropathy: 28 cases of which it was impossible to determin whether the kidney was victim or a cause of arterial hypertension.

\section{Factors of mortality}

We observed 34 cases (11.30\%) of death among our patients. The complications related to these cases are shown in table 2 . 
Table 2. Distribution according to factors of mortality

\begin{tabular}{lllll}
\hline & Dead & Living & $X 2$ & $P$ \\
& $\mathrm{~N}=34$ & $\mathrm{~N}=266$ & & \\
\hline & & & & \\
Cerebrral stroke & $16(47.0 \%)$ & $47(17.7 \%)$ & 15.621 & $\mathrm{P}<0.001$ \\
Renal failure & $12(35.3 \%)$ & $36(13.5 \%)$ & 10.62 .1 & $\mathrm{P}<0.001$ \\
Cardiac failure & $9(26.5 \%)$ & $78(29.32 \%)$ & 0.119 & $\mathrm{NS}$ \\
Encephalopathy & $5(14.7 \%)$ & $52(19.5 \%)$ & 0.459 & $\mathrm{Ns}$ \\
Diabetes & $4(1.7 \%)$ & $21(7.9 \%)$ & 0.591 & $\mathrm{Ns}$ \\
\hline
\end{tabular}

\section{Role of the tensional figures}

The role of tensional figures in mortality rates are illustrated in table 3.

Table 3. Mortality according to high tensional figures

\begin{tabular}{llll}
\hline Arterial hypertension & $N$ & $\begin{array}{l}\text { Dead } \\
\text { patients }\end{array}$ & $\%$ \\
\hline High systolic / diastolic hypertension & 26 & 8 & 30.76 \\
High systolic hypertension & 18 & 4 & 22.2 \\
High diastolic hypertension & 20 & 2 & 10.5 \\
Others (SBP < 240 - SDP < 140) & 236 & 20 & 8.5 \\
\hline
\end{tabular}

We noted in our study that neither age, sex, nor the duration of hypertension were the exclusive severity factors.

\section{Discusion}

Neurosensorial functional symptomatology was the main reason of consultation in our study like in other African series [3]. It was principally dizziness $(38.33 \%)$, followed by headaches $(35 \%)$. More than $75 \%$ of hypertensive patients followed at medical emergencies had moderate to severe hypertension ( $78.8 \%$ cases).

We observed that number of hyper systolic pressure and hyper diastolic pressure are nearly equal. High hypertension was observed in $8.6 \%$ of our patients. These figures are lower than those reported by Renambot (17.4\%) at the Institute of Cardiology in Abidjan [2].

Neurosensorial complicatins were the most frequent clinical feature in our study (120 cases - 40\%). Among these patients we found hypertensive encephalopathy in $19 \%$ cases and cerebrovascular accident in $21 \%$ cases. $60 \%$ of these presented with major accident.

Cerebrovascular accidents are the most frequent complications in Black African and often reveale the hypertensives and cause death from 5 to $37.9 \%$ [36].

In this study 87 patients (29\%) had cardiac diseases. 63 cases $(21 \%)$ with left cardiac failure and 24 cases
(8\%) with global cardiac failure. The rate of mortality was $9.52 \%$ in the first group and $12.50 \%$

in the second group, with a total rate of mortality of $10.35 \%$ for all cardiac patients.

Most of the other African observations agree that in hypertensive Black African, congestive heart failure occured more frequently than ischemic heart disease [3]

In our work, 48 patients (16\%) presented with renal disease of which 38 cases with organic renal failure. Other studies on chronic renal failure in Tropical Africa and in south African Blacks found that hypertensive renal disease is a major cause of chronic renal failure [1-2]. Hypertension is also a major cause of end - stage renal failure in Blacks in USA with an almost eight folds higher age and sex adjusted incidence than whites. In UK, Pazianas [11] found that hypertension was the most important cause of end-stage renal failure in Afro-Caribbeans, being found in 23 of $55(41.8 \%)$ of their patients.

There were 92 cases of hypertension (30.66\%) without clinical signes; 3 of these patients had high hypertension. This means that asympomatic hypertension does not prejudge its severity.

Essential hypertension was found in 255 patients $(85 \%)$ for whom we couldn't find any cause. However, in 45 hypertensive patients (15\%), etiology could be found which was mainly renal disease.

The rate of mortality in hypertensive patients was significantly, higher $(P<0.001)$ than other diseases received at the medical emergencies during the same period $(12.9 \%$ (80/160) VS $7.2 \%(498 / 6871)$.

Comparing the prevalence of complications between dead and the living patients showed that cerebral stroke and renal failure were the major factors of mortality with significant difference $(\mathrm{P}<0.001)$. But heart failure, hypertensive encephalopathy and diabetes were infrequent in the group of dead patients.

As far as tensional figures concerned, there was a correlation between the average figures of blood pressure and mortality. The mean of systolic pressure was over $271.2 \mathrm{mmhg}$ in dead patients $(\mathrm{P}<0.001)$ and the mean of diastolic pressure was over $126.5 \mathrm{mmhg}$ $(\mathrm{P}<0.02)$. We also noticed that for both diastolic and systolic blood pressure there was significant increase of mortality rate $(\mathrm{P}<0.05$ and $\mathrm{P}<0.001$ respectively).

Although the rate of mortality increased with the level of blood pressure yet, the rate of this increase was not the same in the group of high hypertension. In conclusion, hypertensives presented to the medical emergencies at Treichville Teaching Hospital have pejorative prognosis especially, when blood pressure is high and when there are cqrebral stroke and or renal failure. 


\section{References}

1. Bertrand (Ed.): "Hypertension artérielle" In: Précis de pathologie cardio vasculaire tropicale Ed. SANDOZ, 1979; 186-208.

2. Renambot J., Adoh Adoh M., Ekra A., Odi Assamoi M. Bertand Ed. Les super-hypertension artérielles (poussés hypertension 250/120).

3. Coulaud J. P., Gaxdite P., Porta M.: "Complications cérébrovasculaires, rénales et cardiaques" au cours de l'hypertension artérielle en Afrique Noire. In: l'hypertension artérielle en Afrigue aujourd'hui. (Symposium satellite du 8ème congrès de la société Internationale de l'hypertension, MILAN, 3-4 Juin 1981). SIDEM Editeur - Paris, 1982; 220-223.

4. Sankale M., Koate P.: Place et aspects de l'hypertension artérielle dans la pathologie cardio-vasculaire du Noir au Sénégal. Méd. Afr. Noire, 1971; 18-29.

5. Abooud O. L., Osman E. M., Musa A. R.: The aetiology of chronic renal failure in adulte Sudanese patients. Ann. Trop Med. Parasitol, 1989; 83:411-414.
6. Akinsola W., Odesanmi W. O., Ogunniyi J. O. Ladipo. G. O. Diseases causing chronic renal failure in Nigerians. A prospective study of 100 cases Afr. J. Méd. Sci 1989; 18: 131-137.

7. Matekole M., Affram K, Lee J. S., Howie A. J., Michael J., Adv D.: Hypertension and end-stage renal failure in tropical Africa. Journal of Human Hypertension, 1993; 7: 443-446.

8. Oyediran A. B.. Akingkube O.O.: Chronic renal failure in Nigeria Trop Geograph Med. 1970: 22: 41-44.

9. Seedat Y. K.. Naicker S., Rawat R. Parsoo I.: Racial differences in the cause of en-stage renal failure in Natal. South Afr. Med. J., 1984; 65: 956-958.

10. US Renal Data System. USRDS 1989 Annual Report Bethesda Natonal Institutes of Diabetes an Digestive and Kidney Diseases.

11. Pazianas M., Eastwood, J. B., Macrae K. D., Phillip M. E.: Racial origin and primary renal diagnosis in 77 patients with end stage renal disease Nephrol. Dial. transp., 1991; 6:931938 . 